\title{
Quaternary ammonium biocides as antimicrobial agents protecting historical wood and brick*
}

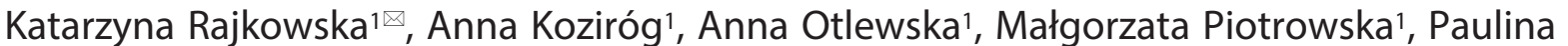 \\ Nowicka-Krawczyk², Bogumił Brycki ${ }^{3}$, Alina Kunicka-Styczyńska ${ }^{1}$ and Beata Gutarowska ${ }^{1}$ \\ IInstitute of Fermentation Technology and Microbiology, Faculty of Biotechnology and Food Sciences, Lodz University of Technology, Łódź, \\ Poland; '2Department of Algology and Mycology, Faculty of Biology and Environmental Protection, University of Lodz, Łódź, Poland; ; Laboratory \\ of Microbiocides Chemistry, Faculty of Chemistry, Adam Mickiewicz University, Poznań, Poland
}

\begin{abstract}
Quaternary ammonium compounds (QACs) are widely used in disinfection of water, surfaces and instruments as well as in textile, leather and food industries because of their relatively low toxicity, broad antimicrobial spectrum, non-volatility and chemical stability. Due to these advantages, QACs are also used in restoration and can be applied on historical material. The aim of this study was to determine the usefulness of biocides based on quaternary ammonium salts and containing various excipients in the protection of historical materials against microbial growth. The study determined the antimicrobial activity of three biocides against bacteria: Pseudomonas fluorescens, Staphylococcus equorum, Bacillus cereus, Bacillus muralis, Sporosarcina aquimarina and Rhodococcus fascians, and moulds: Chaetomium globosum, Penicillium citreonigrum, Cladosporium cladosporioides I, Acremonium strictum, Aspergillus fumigatus and Cladosporium cladosporioides II, all isolated from historical wood and brick. Staphylococcus equorum, Bacillus cereus, Sporosarcina aquimarina and Rhodococcus fascians bacteria, and Cladosporium cladosporioides I and Acremonium strictum moulds showed high sensitivity to quaternary ammonium biocides. Historical wood can be effectively disinfected by three applications of biocide $A$ $(30 \% \mathrm{v} / \mathrm{v})$ containing dodecyl dimethyl ammonium chloride (DDAC), citric acid, propiconazole and propanol. Disinfection of historical brick can be carried out by three applications of $6 \% \mathrm{v} / \mathrm{v}$ solutions of biocide B (based on DDAC and ethylenediaminetetraacetic acid - EDTA) or biocide $C$ (containing a non-ionic surfactant, DDAC and EDTA). Effective protection of historical building materials against microbial growth for a period of seven days can be achieved by the application of biocide A $(30 \%$ $v / v)$ on the wood surface and biocide $B(6 \% v / v)$ on the brick surface.
\end{abstract}

Key words: quaternary ammonium salts, biocides, antibacterial and antifungal activity, protection against development of microorganisms, building historical material

Received: 28 July, 2015; revised: 06 October, 2015; accepted: 30 October, 2015; available on-line: 03 December, 2015

\section{INTRODUCTION}

Quaternary ammonium compounds (QACs) are surfactants, and in 2004 the annual consumption of QACs in the world was estimated at 500000 tons (Tezel \& Pavlostathis, 2011). The structure of these compounds is formed by a positively charged nitrogen $(\mathrm{N})$ atom and four alkyl groups $\mathrm{R}_{1}-\mathrm{R}_{4}$ (saturated, unsaturated, branched or straight, cyclic or acyclic), one of which is a long alkyl chain having different numbers of carbon atoms and a chloride or bromide anion $\left(\mathrm{X}^{-}\right)$, according to the formula $\left[\mathrm{R}_{1} \mathrm{R}_{2} \mathrm{R}_{3} \mathrm{R}_{4} \mathrm{~N}\right]^{+} \mathrm{X}^{-}$.

The alkyl chain is the hydrophobic part of the compound, and nitrogen with alkyl groups is the hydrophilic group. Positively charged complex ions affect the capability of reducing surface tension, which gives these compounds high surface activity. Compounds having 12-14 carbon atoms in the aliphatic chain show the highest surface activity. In turn, negatively charged chlorine ions increase the biocidal activity (Obłąk \& Gamian, 2010; Lipińska-Ojrzanowska \& Walasiuk-Skorupa, 2014). Due to the broad spectrum of activity and high thermal stability, among others, QACs are used as active ingredients in biocides. The most commonly used are benzalkonium chloride (CAS 68989-00-4), dodecyl dimethyl ammonium chloride (CAS 7173-51-5), benzyl-C12-16-alkyldimethyl ammonium chlorides (CAS 68424-85-1), alkyl benzyl dimethyl ammonium chloride (CAS 61789-71-7), benzyl-C8-18-alkyl dimethyl ammonium chloride (CAS: 63449-41-2), dodecyl benzyl dimethyl ammonium bromide (CAS 7281-04-1) and dodecyl dimethyl ammonium bromide (CAS 2390-68-3) (Register of Biocidal Products, Part III).

The antimicrobial effectiveness of QACs was described in the thirties of the twentieth century, indicating their high activity against bacteria, moulds and lipophilic viruses, at very low concentrations (Tischer et al., 2012). The sensitivity of microorganisms to their activity varies depending mainly on concentration and contact time, but also on individual sensitivity of a given strain. It has been found that QACs are more efficient against Grampositive than Gram-negative bacteria. When QACs are used as disinfectants, the concentration applied is almost always below 1000 ppm (Tezel \& Pavlostathis, 2011; Lipińska-Ojrzanowska \& Walasiuk-Skorupa, 2014). They are used in medicine and many industries (food, cosmetics, paper) as biocides and even drugs (Raghavendra, 2002; Xiao et al., 2008). They are readily biodegradable, not toxic to humans and animals, dissolve well in water and are active in a wide $\mathrm{pH}$ range (4-10). In addition,

e-mail: katarzyna.rajkowska@p.lodz.pl

*The results were presented at the 6th International Weigl Conference on Microbiology, Gdańsk, Poland (8-10 July, 2015).

Abbreviations: QACs, quaternary ammonium compounds; DDAC, dodecyl dimethyl ammonium chloride; EDTA, ethylenediaminetetraacetic acid 
they are used as agents to combat biofilms formed by microorganisms in cooling systems (Rucka et al., 1983). Quaternary ammonium salts are also used in the restoration of historical buildings (Karbowska-Berent et al., 2011; Sterflinger \& Piñar, 2013; Stupar et al., 2014), as ingredients of pesticides and wood preservatives (Dubois \& Ruddick, 1998; Tezel \& Pavlostathis, 2011), where they primarily act as antifungal compounds. They are also used as chemical corrosion inhibitors, plasticizers in the production of textiles and paper, or antistatic agents for materials such as cotton or cellulose fibres (Obłąk \& Gamian, 2010; Lipińska-Ojrzanowska \& Walasiuk-Skorupa, 2014).

As quaternary ammonium salts show high antimicrobial activity, have no destructive impact on historical material (Sterflinger \& Piñar 2013), and are often used as active substances in biocidal products, biocides containing these particular compounds have been selected for the study on the protection of historical materials against microbial growth. The tested biocides contain dodecyl dimethyl ammonium chloride and various excipients that can potentially modulate the lethal activity of the formulations. Environmental strains of microorganisms isolated from historical materials were used in this study. While the activity of biocides against collection microorganisms has been commonly tested in vitro, there are still few studies on their efficacy against specific strains of bacteria and moulds that have strongly adapted to historical nutrient-poor materials. The aim of this study was to select quaternary ammonium biocides for effective eradication of microorganisms inhabiting historical wood and brick in situ.

\section{MATERIALS AND METHODS}

Microorganisms. The effectiveness of biocides was tested for six selected strains of bacteria and six strains of moulds isolated from the surfaces of historical wooden and brick barracks at the Auschwitz II - Birkenau State Museum in Oświęcim, i.e. bacteria: Pseudomonas fluoresens, Staphylococcus equorum, Bacillus cereus and moulds: Chaetomium globosum, Cladosporium cladosporioides I, Penicillium citreonigrum on wood; bacteria: Bacillus muralis, Sporosarcina aquimarina, Rhodococcus fascians and moulds: Acremonium strictum, Aspergillus fumigatus, Cladosporium cladosporioides II on brick. The nucleotide sequences of the 16S rRNA gene of the bacteria used in the study were deposited in GenBank, National Centre for Biotechnology Information (Pseudomonas fluorescens KM036083.1; Staphylococcus equorum KM036089.1; Bacillus cereus KM036070.1; Bacillus muralis KM036074.1; Sporosarcina aquimarina KM036087.1; Rhodococcus fascians KM036086.1). Mould strains were deposited in the Culture Collection LOCK 105 under the collection numbers Chaetomium globosum LOCK 0591, Cladosporium cladosporioides I LOCK 0592, Penicillium citreonigrum LOCK 0597, Acremonium strictum LOCK 0595 , Aspergillus fumigatus LOCK 0596 and Cladosporium cladosporioides II LOCK 0593.

Historical materials. Historical materials in the form of wood and brick fragments measuring $50 \times 20 \times 10 \mathrm{~mm}$, collected from the Auschwitz II Birkenau State Museum in Oświęcim, were used in the study (Fig. 1). Samples of the materials were sterilized twice at $121^{\circ} \mathrm{C}$ for fifteen minutes and then stabilized in a constant climate chamber (Binder) at $28^{\circ} \mathrm{C}$ and relative humidity $(\mathrm{RH})$ of $80 \%$ for seven days.

Biocides. Three commercial biocides designated as A, $\mathrm{B}$, and $\mathrm{C}$ were used. The tested formulations contained
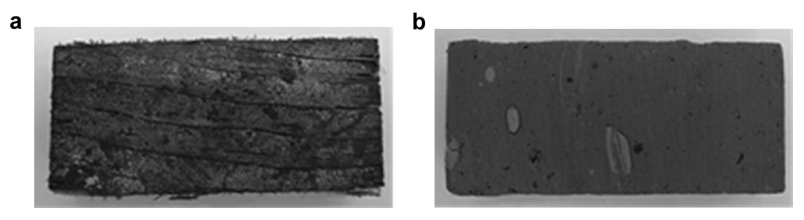

Figure 1. Samples of historical materials (a) wood, (b) brick

dodecyl dimethyl ammonium chloride as the active ingredient and various excipients (Table 1). According to their purpose, biocides $\mathrm{A}$ and $\mathrm{B}$ were applied to the surface of the wood, and biocides $B$ and $C$ on the surface of the brick. Each biocide was tested at three concentrations, according to the manufacturers' recommendations.

Evaluation of antimicrobial activity of biocides in situ on the samples of wood and brick. One millilitre of monocultures of bacteria $\left(10^{8} \mathrm{CFU} / \mathrm{ml}\right)$ or moulds $\left(10^{6}\right.$ conidia $\left./ \mathrm{ml}\right)$ in the medium $\left(\left(\mathrm{NH}_{4}\right)_{2} \mathrm{SO}_{4} 0.075 \%\right.$, $\mathrm{K}_{2} \mathrm{HPO}_{4} 0.025 \%, \mathrm{MgSO}_{4} \times 7 \mathrm{H}_{2} \mathrm{O} 0.125 \%$, yeast extract $0.125 \%$, glucose $0.5 \%$, agar $0.1 \%, \mathrm{pH} 6.0$ ) was applied on the surface of each sample tested. The samples were incubated in a constant climate chamber with a relative humidity of $80 \%$ and a temperature of $28^{\circ} \mathrm{C}$ for 7 days (bacteria) or 21 days (moulds). After incubation, biocides were applied on the surfaces of the wood and brick samples one, two, and three times at an interval of 24 hours, using the spraying method (professional sprayer Mercury Super Pro 360, Quasar). The number of microorganisms after successive applications of each biocide was determined by the contact plate method in TSA medium (Tryptic Soy Agar, Merck) - bacteria, and MEA (Malt Extract Agar, Merck) - moulds. Cultures were incubated at $30^{\circ} \mathrm{C}$ for 48 hours (bacteria) and at $28^{\circ} \mathrm{C}$ for 5 days (moulds).

Evaluation of the effectiveness of protection of the historical materials against microbial growth. On the surface of each sterile, conditioned sample of historical wood and brick, the biocides were applied three times at an interval of 30 minutes, followed by an inoculum of bacteria $\left(10^{8} \mathrm{CFU} / \mathrm{ml}\right)$ or moulds $\left(10^{6}\right.$ conidia $\left./ \mathrm{ml}\right)$. The samples were incubated in a constant climate chamber $\left(28^{\circ} \mathrm{C}, 80 \% \mathrm{RH}\right)$. The effectiveness of the protection of the material against microbial growth was determined by the contact plate method in TSA medium (bacteria) and MEA (moulds) after 7 and 28 days of the treatment, similarly as in the tests of the antimicrobial activity.

The evaluation scale for the antimicrobial activity of the biocides on the surfaces of historical materials. In order to determine the activity of the biocides against bacteria and moulds, a calibration scale was used according to Table 2 .

\section{RESULTS AND DISCUSSION}

The antimicrobial activity of biocides was determined using microorganisms isolated from historical wood and brick surfaces with visible signs of deterioration (Koziróg et al., 2014; Rajkowska et al., 2014; Piotrowska et al., 2014). Moulds and bacteria colonizing historical materials may cause serious aesthetical destruction, inhabit and penetrate into the materials, resulting in material loss, due to acid corrosion, enzymatic degradation and mechanical attack (Sterflinger \& Piñar, 2013). Effective protection of historical material against microorganisms provides a properly conducted disinfection and protection against re-colonization by bacteria and moulds 
Table 1. Biocides used in the tests

\begin{tabular}{lll}
\hline Biocide & Content of the active substance [\%] & Concentrations used in the tests [\% v/v] \\
\hline A & $\begin{array}{l}\text { dodecyl dimethyl ammonium chloride }(\mathrm{DDAC})<9.5 \% \\
\text { citric acid } 2.0 \% \\
\text { propiconazole } 0.5 \% \\
(2-\text { methoxymethylethoxy) propanol } 0.5 \%\end{array}$ & $10,20,30$ \\
\hline B & $\begin{array}{l}\text { dodecyl dimethyl ammonium chloride }(\mathrm{DDAC})<5.0 \% \\
\text { ethylenediaminetetraacetic acid (EDTA) }<5.0 \%\end{array}$ & $1.5,3,6$ \\
\hline & $\begin{array}{l}\text { non-ionic surfactant } 5.0-10.0 \% \\
\text { dodecyl dimethyl ammonium chloride }(\mathrm{DDAC}) \leq 5.0 \% \\
\text { ethylenediaminetetraacetic acid (EDTA) } £ 2.0 \%\end{array}$ & $1.5,3,6$ \\
\hline
\end{tabular}

(Koziróg \& Żakowska, 2014). The study was carried out on historical wood and brick samples using three biocides based on quaternary ammonium salts but containing various excipients, i.e. biocide A - DDAC, citric acid, propiconazole and propanol, biocide $\mathrm{B}-\mathrm{DDAC}$ and EDTA, biocide $\mathrm{C}$ - non-ionic surfactant, DDAC and EDTA.

The tested mould and bacteria strains showed varying susceptibility to the biocides. In general, Chaetomium globosum, Penicillium citreonigrum, Aspergillus fumigatus and Cladosporium cladosporioides (II) moulds demonstrated lower sensitivity (Tables 3, 4 and 7). P. citreonigrum and Ch. globosum on wood samples were insensitive to biocide B at all tested concentrations. Ch. globosum was sensitive to $20 \%$ and $30 \% \mathrm{v} / \mathrm{v}$ biocide $\mathrm{A}$, but only after its third application. While $P$. citreonigrum showed sensitivity to preparation $\mathrm{A}$ at the lowest concentration of $10 \% \mathrm{v} / \mathrm{v}$, it also required its three applications (Table 3). On brick samples, A. fumigatus and C. cladosporioides (II) exhibited insensitivity to biocides $\mathrm{B}$ and $\mathrm{C}$, both at concentration of $1.5 \% \mathrm{v} / \mathrm{v}$. C. cladosporioides (II) was highly sensitive to preparations $\mathrm{B}$ and $\mathrm{C}$ at concentration of $3 \% \mathrm{v} / \mathrm{v}$ after three applications, or $6 \% \mathrm{v} / \mathrm{v}$ after two applications (Table 4). At the same time, for eradication of $A$. fumigatus from the brick surface, three applications either of biocide $\mathrm{B}(3 \%$ or $6 \% \mathrm{v} / \mathrm{v})$ or biocide C $(3 \%$ or $6 \% \mathrm{v} / \mathrm{v})$ were necessary.

Table 2. A method of evaluating antimicrobial activity of biocides

\begin{tabular}{|c|c|c|c|c|}
\hline Biocidal activity & Bacteria & $\begin{array}{l}\text { Reduction in the number } \\
\text { of bacteria }\end{array}$ & Moulds & $\begin{array}{l}\% \text { of the surface contamination } \\
\text { of samples }\end{array}$ \\
\hline $\begin{array}{l}\text { high } \\
+++\end{array}$ & & $8 \log$ & & no growth \\
\hline $\begin{array}{l}\text { good } \\
++\end{array}$ & & $6 \log$ & & $25 \%$ \\
\hline $\begin{array}{l}\text { low } \\
+\end{array}$ & & $4 \log$ & & $50 \%$ \\
\hline $\begin{array}{l}\text { very low } \\
+/-\end{array}$ & & $2 \log$ & & $75 \%$ \\
\hline no activity & & no reduction & & $100 \%$ \\
\hline
\end{tabular}

In comparison to the other bacteria tested, less sento biocide $\mathrm{B}$ and Bacillus muralis to biocides $\mathrm{B}$ and $\mathrm{C}$ (Tables 3, 4 and 7). P. fluorescens on wood samples was highly sensitive to $10 \% \mathrm{v} / \mathrm{v}$ biocide $\mathrm{A}$, but only after its third application, or to $20 \% \mathrm{v} / \mathrm{v}$ biocide A already after the first use (Table 3). Still, the complete inhibition of $B$. muralis growth on brick surface required three applications of $6 \% \mathrm{v} / \mathrm{v}$ biocide $\mathrm{C}$ (Table 4).

Quaternary ammonium compounds (QACs) are considered to be membrane active agents (McDonnell \& Russell, 1999). In microbial cells exposed to QACs, there are sequential processes of adsorption and penetration of the agent into the cell wall, reaction with the cytoplasmic membrane followed by membrane disorganization, leakage of intracellular low-molecular-weight material, degradation of proteins and nucleic acids and wall lysis caused by the autolytic enzymes (Tischer et al., 2012).

Regardless of the mechanism of action, different types of microorganisms vary in their response to disinfectants. Generally, Gram-negative and spore-forming bacteria show lower sensitivity to biocides (Maillard, 2002). This classification is consistent with the results obtained in this study, indicating that Bacillus muralis and Pseudomonas fuorescens bacteria, but also moulds, are less sensitive to QACs. Lower sensitivity may be attributed, depending on the cell structure, to the outer membrane in Gramsitive were two bacterial strains of Psendomonas fluorescens 
Table 3. Antimicrobial activity of biocides on wood samples

\begin{tabular}{|c|c|c|c|c|c|c|c|}
\hline \multirow{2}{*}{$\begin{array}{l}\text { Biocide/ } \\
\text { concentration } \\
{[\% \mathrm{v} / \mathrm{v}]}\end{array}$} & \multirow{2}{*}{$\begin{array}{l}\text { Number } \\
\text { of applications }\end{array}$} & \multicolumn{3}{|l|}{ Bacteria } & \multicolumn{3}{|l|}{ Moulds } \\
\hline & & P. fluoresens & S. equorum & B. cereus & Ch. globosum & C. cladosporioides I & P. citreonigrum \\
\hline \multicolumn{8}{|l|}{ Biocide A } \\
\hline \multirow{3}{*}{10} & 1 & $+/-$ & +++ & +++ & - & + & - \\
\hline & 2 & ++ & +++ & +++ & - & + & $+/-$ \\
\hline & 3 & +++ & +++ & +++ & $+/-$ & ++ & ++ \\
\hline \multirow{3}{*}{20} & 1 & +++ & +++ & +++ & - & + & - \\
\hline & 2 & +++ & +++ & +++ & $+/-$ & + & + \\
\hline & 3 & +++ & +++ & +++ & +++ & ++ & ++ \\
\hline \multirow{3}{*}{30} & 1 & +++ & +++ & +++ & - & + & - \\
\hline & 2 & +++ & +++ & +++ & + & ++ & + \\
\hline & 3 & +++ & +++ & +++ & +++ & +++ & ++ \\
\hline \multicolumn{8}{|l|}{ Biocide B } \\
\hline \multirow{3}{*}{1.5} & 1 & - & +++ & ++ & - & - & - \\
\hline & 2 & $+/-$ & +++ & ++ & - & + & - \\
\hline & 3 & $+/-$ & +++ & +++ & - & ++ & $+/-$ \\
\hline \multirow{3}{*}{3} & 1 & - & +++ & +++ & - & $+/-$ & - \\
\hline & 2 & $+/-$ & +++ & +++ & - & ++ & - \\
\hline & 3 & $+/-$ & +++ & +++ & - & +++ & $+/-$ \\
\hline \multirow{3}{*}{6} & 1 & - & +++ & +++ & - & + & - \\
\hline & 2 & $+/-$ & +++ & +++ & - & ++ & - \\
\hline & 3 & $+/-$ & +++ & +++ & - & +++ & + \\
\hline
\end{tabular}

Symbols with respect to biocidal activity: +++ high, ++ good, + low, +/- very low, - no activity

negative bacteria, which acts as a permeability barrier and restricts entry of many types of chemicals, or to the presence of a resistant wall in bacterial endospores and fungal conidia (White \& McDermott, 2001). It should be emphasized, however, that microbial susceptibility to antiseptics and disinfectants is a strain-dependent feature.

As for the strains with lower sensitivity to the tested quaternary ammonium biocides, a high or good antimicrobial activity was achieved on wood samples after three applications of $30 \% \mathrm{v} / \mathrm{v}$ biocide $\mathrm{A}$, containing DDAC, citric acid, propiconazole and propanol (Tables 3 and 4). On the other hand, brick samples can be disinfected by three applications of $6 \% \mathrm{v} / \mathrm{v}$ solutions of biocide $\mathrm{B}$ (based on DDAC and EDTA) or biocide $\mathrm{C}$ (containing a non-ionic surfactant, DDAC and EDTA). Biocide B applied on the wood surface was ineffective in inhibiting the growth of P. fluorescens, Ch. globosum and $P$. citreonigrum even at the highest tested concentration of $6 \% \mathrm{v} / \mathrm{v}$ (Table 3).

Earlier studies conducted in the museum's environment showed that the total number of microorganisms on the surfaces of the tested historical materials did not exceed $10^{5} \mathrm{CFU} / 100 \mathrm{~cm}^{2}$ (Koziróg et al., 2014; Rajkowska et al., 2014). Taking into account the number of microorganisms, it can be assumed that these materials can be effectively disinfected using biocides at concentrations corresponding to their good activity. Then, to inhibit the growth of the tested organisms on the wood surface, it should be applied three times for biocide $\mathrm{A}$ at a concentration of $20 \% \mathrm{v} / \mathrm{v}$, and on the brick sample biocide $\mathrm{C}$ at a concentration of $3 \% \mathrm{v} / \mathrm{v}$ (Tables 3 and 4).
The effectiveness of the wood and brick surface protection before recolonization of microorganisms was determined after 7 and 28 days. The effectiveness of the protection was dependent on the biocide and the strain. Similarly to the disinfection process, the protection was less effective against $P$. fluorescens and $B$. muralis bacteria and Ch. globosum, P. citreonigrum, A. fumigatus moulds (Tables 5 and 6). In the case of wood samples, good or high protection was found after using $30 \% \mathrm{v} / \mathrm{v}$ biocide A, but within a period of 7 days. After 28 days of incubation, this biocide did not inhibit the growth of $\mathrm{Ch}$. globosum (Table 5). Biocide $\mathrm{B}$, used at a concentration of $6 \% \mathrm{v} / \mathrm{v}$, limited microbial growth on the brick surface for 7 days. In the long term, however, it did not protect the historical brick surface against the growth of $B$. muralis (Table 6) and the wood surface against the growth of P. fuorescens, Ch. globosum and P. citreonigrum (Table 5).

Inhibition of the growth of five out of six tested microorganisms on the brick samples was observed after use of biocide $\mathrm{C}(6 \% \mathrm{v} / \mathrm{v})$. This biocide, however, did not protect the surface against the growth of $A$. fumigatus, neither within 7 nor 28 days (Table 6).

The efficacy of biocides depends on many factors, including their concentration, the period of contact with microorganisms, the presence of interfering materials (e.g. organic or inorganic soils), temperature as well as the nature and type of target microorganisms (Russell \& McDonnell, 2000). In addition, the efficacy of antimicrobial agents depends on and varies significantly with formulation effects, which can often enhance biocidal activity. 
Table 4. Antimicrobial activity of biocides on brick samples

\begin{tabular}{|c|c|c|c|c|c|c|c|}
\hline \multirow{2}{*}{$\begin{array}{l}\text { Biocide/ } \\
\text { concentration } \\
{[\% \mathrm{v} / \mathrm{v}]}\end{array}$} & \multirow{2}{*}{$\begin{array}{l}\text { Number } \\
\text { of applications }\end{array}$} & \multicolumn{3}{|l|}{ Bacteria } & \multicolumn{3}{|l|}{ Moulds } \\
\hline & & B. muralis & S. aquimarina & R. fascians & A. strictum & A. fumigatus & C. cladosporioides I \\
\hline \multicolumn{8}{|l|}{ Biocide B } \\
\hline \multirow{3}{*}{1.5} & 1 & - & +++ & ++ & +++ & - & - \\
\hline & 2 & - & +++ & ++ & +++ & - & - \\
\hline & 3 & $+/-$ & +++ & ++ & +++ & $+/-$ & - \\
\hline \multirow{3}{*}{3} & 1 & - & +++ & +++ & +++ & - & $+/-$ \\
\hline & 2 & + & +++ & +++ & +++ & - & + \\
\hline & 3 & + & +++ & +++ & +++ & ++ & +++ \\
\hline \multirow{3}{*}{6} & 1 & - & +++ & +++ & +++ & - & ++ \\
\hline & 2 & + & +++ & +++ & +++ & + & +++ \\
\hline & 3 & ++ & +++ & +++ & +++ & +++ & +++ \\
\hline \multicolumn{8}{|l|}{ Biocide C } \\
\hline \multirow{3}{*}{1.5} & 1 & - & ++ & + & +++ & - & - \\
\hline & 2 & - & ++ & + & +++ & - & - \\
\hline & 3 & $+/-$ & +++ & ++ & +++ & - & + \\
\hline \multirow{3}{*}{3} & 1 & + & ++ & ++ & +++ & - & $+/-$ \\
\hline & 2 & + & +++ & ++ & +++ & - & ++ \\
\hline & 3 & ++ & +++ & +++ & +++ & ++ & +++ \\
\hline \multirow{3}{*}{6} & 1 & ++ & +++ & +++ & +++ & - & +++ \\
\hline & 2 & ++ & +++ & +++ & +++ & - & +++ \\
\hline & 3 & +++ & +++ & +++ & +++ & ++ & +++ \\
\hline
\end{tabular}

Symbols with respect to biocidal activity: +++ high, ++ good, + low, +/- very low, - no activity

Table 5. The effectiveness of wood preservation against microbial growth

\begin{tabular}{|c|c|c|c|c|c|c|c|}
\hline \multirow{2}{*}{$\begin{array}{l}\text { Biocide/ } \\
\text { concentration } \\
{[\% \mathrm{v} / \mathrm{v}]}\end{array}$} & \multirow{2}{*}{$\begin{array}{l}\text { Time } \\
\text { after application }\end{array}$} & \multicolumn{3}{|l|}{ Bacteria } & \multicolumn{3}{|l|}{ Moulds } \\
\hline & & P. fluoresens & S. equorum & B. cereus & Ch. globosum & C. cladosporioides I & P. citreonigrum \\
\hline \multicolumn{8}{|l|}{ Biocide A } \\
\hline \multirow{2}{*}{10} & 7 days & $+/-$ & +++ & ++ & - & +++ & ++ \\
\hline & 28 days & +++ & +++ & +++ & - & +++ & ++ \\
\hline \multirow{2}{*}{20} & 7 days & $+/-$ & +++ & +++ & - & +++ & +++ \\
\hline & 28 days & +++ & +++ & +++ & - & +++ & ++ \\
\hline \multirow{2}{*}{30} & 7 days & +++ & +++ & +++ & ++ & +++ & +++ \\
\hline & 28 days & +++ & +++ & +++ & - & +++ & +++ \\
\hline \multicolumn{8}{|l|}{ Biocide B } \\
\hline \multirow{2}{*}{1.5} & 7 days & - & + & +++ & + & + & $+/-$ \\
\hline & 28 days & - & $+/-$ & ++ & - & - & - \\
\hline \multirow{2}{*}{3} & 7 days & - & +++ & +++ & ++ & ++ & ++ \\
\hline & 28 days & - & +++ & ++ & - & ++ & - \\
\hline \multirow{2}{*}{6} & 7 days & $+/-$ & +++ & +++ & ++ & +++ & +++ \\
\hline & 28 days & + & +++ & +++ & + & ++ & + \\
\hline
\end{tabular}

Symbols with respect to biocidal activity: +++ high, ++ good, + low, +/- very low, - no activity 
Table 6. The efficacy of brick protection against microbial growth

\begin{tabular}{|c|c|c|c|c|c|c|c|}
\hline \multirow{2}{*}{$\begin{array}{l}\text { Biocide/ } \\
\text { concentration } \\
{[\% \mathrm{v} / \mathrm{v}]}\end{array}$} & \multirow{2}{*}{$\begin{array}{l}\text { Time } \\
\text { after application }\end{array}$} & \multicolumn{3}{|l|}{ Bacteria } & \multicolumn{3}{|l|}{ Moulds } \\
\hline & & B. muralis & S. aquimarina & R. fascians & A. strictum & A. fumigatus & C. cladosporioides II \\
\hline \multicolumn{8}{|l|}{ Biocide B } \\
\hline \multirow{2}{*}{1.5} & 7 days & + & +++ & +++ & +++ & $+/-$ & ++ \\
\hline & 28 days & $+/-$ & +++ & +++ & +++ & $+/-$ & - \\
\hline \multirow{2}{*}{3} & 7 days & + & +++ & +++ & +++ & +++ & ++ \\
\hline & 28 days & $+/-$ & +++ & +++ & +++ & ++ & +++ \\
\hline \multirow{2}{*}{6} & 7 days & ++ & +++ & +++ & +++ & +++ & +++ \\
\hline & 28 days & $+/-$ & +++ & +++ & +++ & +++ & +++ \\
\hline \multicolumn{8}{|l|}{ Biocide C } \\
\hline \multirow{2}{*}{1.5} & 7 days & + & +++ & ++ & +++ & - & +++ \\
\hline & 28 days & ++ & +++ & +++ & +++ & - & - \\
\hline \multirow{2}{*}{3} & 7 days & + & +++ & +++ & +++ & - & ++ \\
\hline & 28 days & $+/-$ & +++ & $+/-$ & +++ & - & - \\
\hline \multirow{2}{*}{6} & 7 days & ++ & +++ & +++ & +++ & - & +++ \\
\hline & 28 days & ++ & +++ & +++ & +++ & - & ++ \\
\hline
\end{tabular}

Symbols with respect to biocidal activity: +++ high, ++ good, + low, +/- very low, - no activity

Table 7. Antimicrobial and protective activity of the investigated biocides based on the example of biocide $\mathrm{C}$ used on the historical brick samples against Bacillus muralis and Cladosporium cladosporioides II

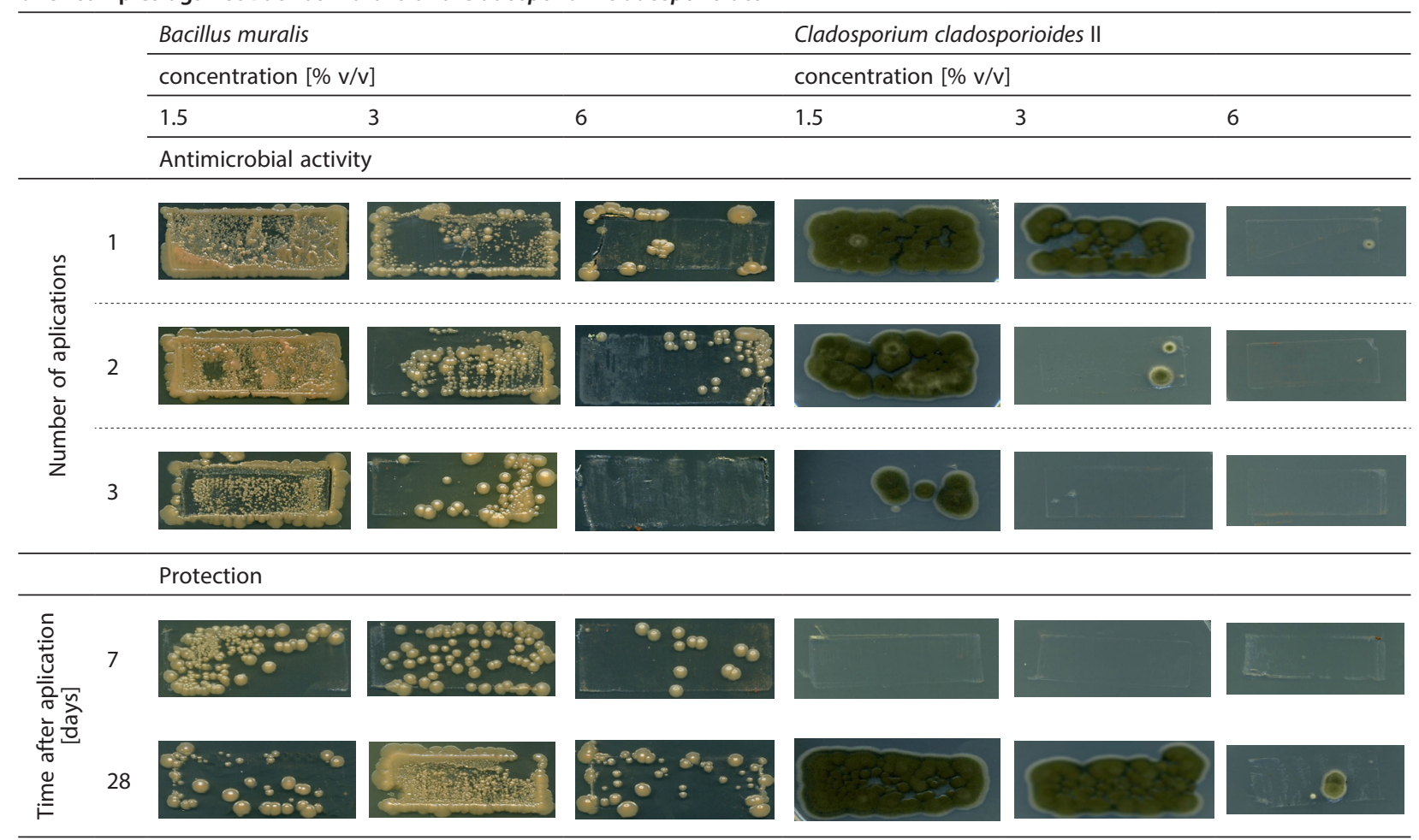

In addition to dodecyl dimethyl ammonium chloride, the active ingredients of biocide $\mathrm{A}$ include a propanol derivative, showing a broad spectrum of antifungal and antibacterial activities, and fungistatic propiconazole (Tang et al., 2013; Picheansathian, 2004). Alcohols cause membrane damage and rapid denaturation of proteins, with subsequent interference in metabolism and cell ly- sis (McDonell \& Russell, 1999). They are also known to inhibit sporulation and spore germination, but this effect is reversible (Trujillo \& Laible, 1970). Lower concentrations of alcohols are used as preservatives and to potentiate the activity of other biocides (Maillard, 2002). Propiconazole's mode of action is demethylation of C-14 during ergosterol biosynthesis, leading to accumu- 
lation of C-14 methyl sterols and abnormalities in the formation of the cell wall of fungi (Kalawate \& Pandey, 2012). In contrast, biocides B and C additionally contain EDTA, a chelating agent that disorganizes phospholipid composition of microorganism membranes, thereby altering the permeability for certain substances and permitting the entry into the cell of chemically unrelated molecules (Al-Bakri et al., 2009).

According to the Regulation of the European Parliament and of the European Council (EU) No 528/2012, concerning the making available on the market and use of biocidal products, labels of biocidal products must contain specified information on every active substance and its concentration. This obligation does not apply to excipients which are present in the formula of biocides and can modulate their antimicrobial activity. Differences in the antimicrobial activity of the tested biocides may thus result from a different content of QACs, the presence of other active ingredients, as well as the presence of additional excipients in the formulations.

Choosing the right concentration of biocide is crucial to ensure proper protection of historical materials against microbial growth, because random multiple detrimental effects have been shown with highly reactive biocides used at high concentrations. When lower concentrations of biocides are used (i.e. inhibitory or sublethal concentrations), the emergence of resistant microorganisms has been reported (Maillard, 2002).

In summary, effective disinfection of historical wood samples against the tested strains of microorganisms can be achieved by three applications of biocide $\mathrm{A}$ at a concentration of $30 \% \mathrm{v} / \mathrm{v}$. On the other hand, historical brick samples can be disinfected by three applications of biocide $\mathrm{B}$ or $\mathrm{C}$ in a concentration of $6 \% \mathrm{v} / \mathrm{v}$. Furthermore, the use of biocide $\mathrm{A}(30 \% \mathrm{v} / \mathrm{v})$ on the wood surface, and biocide B (6\% v/v) on the brick surface, effectively protects these materials against the development of the tested microorganisms for a period of seven days.

\section{Acknowledgements}

We would like to thank the staff of the Preservation Department of the Auschwitz-Birkenau State Museum in Oświęcim for cooperation and providing materials for this research.

\section{REFERENCES}

Al-Bakri AG, Othman G, Bustanji Y (2009) The assessment of the antibacterial and antifungal activities of aspirin, EDTA and aspirin-EDTA combination and their effectiveness as antibiofilm agents. J Appl Microbiol 107: 280-286. http://dx.doi.org/10.1111/j.13652672.2009.04205.x.

Dubois JW, Ruddick JN (1998) The fungal degradation of quaternary ammonium compounds in wood. International Research Group (IRG) on Wood Protection.

Kalawate A, Pandey CN (2012) An antimycotic study of propiconazole for mould inhibition on rubber wood. Int J Fundam Appl Sci 1: 24 26.

Karbowska-Berent J, Kozielec T, Jarmiłko J, Brycki B (2011) Possible application of quaternary ammonium salts for disinfection of paper based objects. Restaurator 32: 223-246. http://dx.doi.org/10.1515/ rest.2011.011.

Koziróg A, Otlewska A, Piotrowska M, Rajkowska K, Nowicka-Krawczyk P, Hachułka M, Wolski GJ, Gutarowska B, Kunicka-Styczyńska A, Libudzisz Z, Żakowska Z, Żydzik-Białek A (2014) Colonising organisms as a biodegradation factor affecting historical wood materials at the former concentration camp of Auschwitz II - Birke- nau. Int Biodeter Biodegr 86: 171-178. http://dx.doi.org/10.1016/j. ibiod.2013.08.004.

Koziróg A, Żakowska Z (2014) What determines the effective disinfection? In Protection of buildings against moisture and biological corrosion. Skowroński W, ed, 10, t IX, pp 46-51. Polskie Stowarzyszenie Mykologów Budownictwa, Wrocław (in Polish).

Lipińska-Ojrzanowska A, Walasiuk-Skorupa J (2014) Quaternary ammonium compounds - new occupational hazards. Med $\operatorname{Pr}$ 65: 675682. http://dx.doi.org/10.13075/mp.5893.00056 (in Polish).

Maillard JY (2002) Bacterial target sites for biocide action. J Appl Microbiol Suppl 92: 16S-27S. http://dx.doi.org/10.1046/j.13652672.92.5s1.3.x.

McDonnell G, Russell AD (1999) Antiseptics and disinfectants: activity, action, and resistance. Clin Microbiol Rev 12: 147-179.

Obłak E, Gamian A (2010) The biological activity of quaternary ammonium salts (QASs). Postepy Hig Med Dosw 64: 201-211 (in Polish).

Picheansathian W (2004) A systematic review on the effectiveness of alcohol-based solutions for hand hygiene. Int I Nurs Pract 10: 3-9. http://dx.doi.org/10.1111/j.1440-172X.2003.00457.x.

Piotrowska M, Otlewska A, Rajkowska K, Koziróg A, Hachułka M, Nowicka-Krawczyk P, Wolski GJ, Gutarowska B, Kunicka-Styczyńska A, Żydzik-Białek A (2014) Abiotic Determinants of the historical buildings biodeterioration in the former Auschwitz II Birkenau concentration and extermination camp. Plos One 9: 109402. http://dx.doi.org/ 10.1371/journal.pone.0109402.

Raghavendra T (2002) Neuromuscular blocking drugs: discovery and development. J R Soc Med 95: 363-367.

Rajkowska K, Otlewska A, Koziróg A, Piotrowska M, Nowicka-Krawczyk P, Hachułka M, Wolski GJ, Kunicka-Styczyńska A, Gutarowska B, Żydzik-Białek A (2014) Assessment of biological colonization of historic buildings in the former Auschwitz II - Birkenau concentration camp. Ann Microbiol 64: 799-808. http://dx.doi.org/10.1007/ s13213-013-0716-8.

Regulation (EU) no 528/2012 of the European Parliament and of the Council of 22 May 2012 concerning the making available on the market and use of biocidal products. Official Journal of the European Union L 167/1, 27.6.2012.

Register of Biocidal Products, Part III - containing a list of biocidal products which have been granted a marketing authorization (Article 54 of the law on biocidal products) http://bip.urpl.gov.pl/article/rejestr-produktow-biobojczych.

Rucka M, Oświęcimska M, Witek S (1983) New biocides for cooling water treatment. III. Quaternary ammonium salts derivatives of glycine esters. Environ Prot Eng 9: 25-31.

Russell AD, McDonnell G (2000) Concentration: a major factor in studying biocidal action. J Hosp Infect 44: 1-3. http://dx.doi. org/10.1053/jhin.1999.0654.

Sterflinger K, Piñar G (2013) Microbial deterioration of cultural heritage and works of art - tilting at windmills? Appl Microbiol Biotechnol 97: 9637-9646. http://dx.doi.org/10.1007/s00253-013-5283-1.

Stupara M, Grbića ML, Džamića A, Unkovića N, Ristićb M, Jelikićc A, Vukojevića J (2014) Antifungal activity of selected essential oils and biocide benzalkonium chloride against the fungi isolated from cultural heritage objects. S Afr J Bot 93: 118-124. http://dx.doi. org/10.1016/j.sajb.2014.03.016.

Tang R, Jin L, Mou C, Yin J, Bai S, Hu D, Wu J, Yang S, Song B (2013) Synthesis, antifungal and antibacterial activity for novel amide derivatives containing a triazole moiety. Chem Cent J 2013, 7: 30-36. http://dx.doi.org/10.1186/1752-153X-7-30.

Tezel U, Pavlostathis SG (2011) Role of quaternary ammonium compounds on antimicrobial resistance in the environment. In Antimicrobial resistance in the environment. Keen PL, Montforts MHMM, eds, pp 349-388. Wiley-Blackwell, John Wiley \& Sons, Hoboken, NJ. http://dx.doi.org /10.1002/9781118156247.ch20.

Tischer M, Pradel G, Ohlsen K, Holzgrabe U (2012) Quaternary ammonium salts and their antimicrobial potential: targets or nonspecific interactions? Chem Med Chem 7: 22-31. http://dx.doi.org /10.1002/cmdc.201100404.

Trujillo R, Laible N (1970) Reversible inhibition of spore germination by alcohols. Appl Microbiol 20: 620-623.

White DG, McDermott PF (2001) Biocides, drug resistance and microbial evolution. Curr Opin Microbiol 4: 313-317. http://dx.doi.org /10.1016/S1369-5274(00)00209-5.

Xiao YH, Chen JH, Fang M, Xing XD, Wang H, Wang YJ, Li F (2008) Antibacterial effects of three experimental quaternary ammonium salt (QAS) monomers on bacteria associated with oral infections. J Oral Sci 50: 323-327. http://dx.doi.org/10.2334/josnusd.50.323. 